\title{
Cardiovascular risk factors and mortality in hospitalized patients with COVID-19: systematic review and meta-analysis of 45 studies and 18,300 patients
}

Angelo Silverio', Marco Di Maio', Rodolfo Citro², Luca Esposito², Giuseppe luliano², Michele Bellino², Cesare Baldi², Giuseppe De Luca ${ }^{3}$, Michele Ciccarelli ${ }^{1}$, Carmine Vecchione ${ }^{1,4}$ and Gennaro Galasso ${ }^{1 *}(\mathbb{D}$

\begin{abstract}
Background: A high prevalence of cardiovascular risk factors including age, male sex, hypertension, diabetes, and tobacco use, has been reported in patients with Coronavirus disease 2019 (COVID-19) who experienced adverse outcome. The aim of this study was to investigate the relationship between cardiovascular risk factors and in-hospital mortality in patients with COVID-19.
\end{abstract}

Methods: MEDLINE, Cochrane, Web of Sciences, and SCOPUS were searched for retrospective or prospective observational studies reporting data on cardiovascular risk factors and in-hospital mortality in patients with COVID-19. Univariable and multivariable age-adjusted analyses were conducted to evaluate the association between cardiovascular risk factors and the occurrence of in-hospital death.

Results: The analysis included 45 studies enrolling 18,300 patients. The pooled estimate of in-hospital mortality was 12\% (95\% Cl 9-15\%). The univariable meta-regression analysis showed a significant association between age (coefficient: 1.06; 95\% Cl 1.04-1.09; $\mathrm{p}<0.001$ ), diabetes (coefficient: 1.04; 95\% Cl 1.02-1.07; $p<0.001$ ) and hypertension (coefficient: 1.01; 95\% Cl 1.01-1.03; $\mathrm{p}=0.013$ ) with in-hospital death. Male sex and smoking did not significantly affect mortality. At multivariable age-adjusted meta-regression analysis, diabetes was significantly associated with in-hospital mortality (coefficient: 1.02; 95\% Cl 1.01-1.05; $p=0.043$ ); conversely, hypertension was no longer significant after adjustment for age (coefficient: 1.00; 95\% $\mathrm{Cl} 0.99-1.01 ; \mathrm{p}=0.820$ ). A significant association between age and inhospital mortality was confirmed in all multivariable models.

Conclusions: This meta-analysis suggests that older age and diabetes are associated with higher risk of in-hospital mortality in patients infected by SARS-CoV-2. Conversely, male sex, hypertension, and smoking did not independently correlate with fatal outcome.

Keywords: Novel coronavirus, SARS-CoV-2, COVID-19, Cardiovascular risk factors, Hypertension, Smoking, Diabetes, Mortality, Outcome

\footnotetext{
*Correspondence: ggalasso@unisa.com

1 Department of Medicine, Surgery and Dentistry, University of Salerno, Baronissi, Salerno, Italy

Full list of author information is available at the end of the article
}

\section{Introduction}

Coronavirus disease 2019 (COVID-19) is a recently recognized infective disease caused by a new betacoronavirus, which has sparked in Hubei province, China, and has spread rapidly worldwide taking on pandemic 
proportions. [1] Owing to the frequent involvement of respiratory tract in humans, the viral agent is also known as severe acute respiratory syndrome coronavirus 2 (SARS-CoV-2). [2]

Up to date, COVID-19 has affected over 7 millions of people and has been associated with more than 400 thousand deaths worldwide. [3] A large discrepancy in the rates of mortality has emerged across reports, resulting in an open debate involving healthcare administrators, physicians and researchers in several countries. Beyond the strategies adopted by governments and health-care resources availability, [4] the inconsistency of overall case-fatality rate between centers seems largely influenced by the clinical profile of the patients enrolled. [5, 6]

Previous studies have investigated the association between baseline characteristics and outcome of patients with COVID-19, and have showed that age and multiple comorbidities may precipitate clinical course during hospitalization. [5, 7, 8] Cardiac injury, defined by increased serum troponin levels, emerged as an independent predictor of mortality in COVID-19, particularly when associated to underlying cardiovascular disease. [9] Moreover, traditional cardiovascular risk factors including age, hypertension, diabetes and smoking, were frequently reported in critically ill cases and seemed to affect in-hospital outcome. [9-11] These conditions are highly prevalent in high-income Asian and Western countries and represent a matter of concern, especially considering population growth and ageing. [12].

Whether cardiovascular risk factors may play a role on clinical course and outcome of patient infected by SARS-CoV-2 remains unclear. A quantitative synthesis of observational data may help to understand the effect of cardiovascular risk factors on the outcome of patients hospitalized for COVID-19, and to identify parameters potentially useful for prognostic stratification.

The aim of this meta-analysis was to investigate the burden of cardiovascular risk factors and the rate of fatal outcome in patients infected by SARS-CoV-2, and to explore their relationship during hospitalization.

\section{Methods}

This study was designed according to the Meta-analysis of Observational Studies in Epidemiology (MOOSE) statement. [13] The review protocol was not registered on PROSPERO.

\section{Data sources and searches}

A comprehensive MEDLINE, Cochrane, Web of Science, and SCOPUS literature search was performed until April 27 , 2020. Studies dealing with the clinical characteristics and outcome of patients hospitalized for COVID19 , including those presented or published in other languages, were selected. Articles in languages other than English were screened by using on-line translators and through contacts with researchers from other countries. The following search strategies were used: (1) MEDLINE-("COVID-19"[All Fields] OR “COVID 19"[All Fields] OR "severe acute respiratory syndrome coronavirus 2"[All Fields] OR "2019-nCoV"[All Fields] OR "SARSCoV-2"[All Fields]) AND ("risk factors"[MeSH terms] OR "hypertension"[All Fields] OR "smoking"[All Fields] OR "age"[All Fields] OR "diabetes"[All Fields] OR "sex"[All Fields] OR "gender"[All Fields] OR "comorbidities"[All Fields] OR "cardiovascular disease"[All Fields] OR "outcome"[All Fields] OR "mortality"[All Fields]); Cochrane Library, Web of Science and SCOPUS"COVID-19" OR "COVID 19" OR "SARS-CoV-2" OR "severe acute respiratory syndrome coronavirus 2 " OR "2019-nCoV". Search was conducted by using the Thomson Reuters EndNote X7 software.

\section{Study selection}

Citations were screened on the title and abstract level by three independent reviewers (A.S., L.E. and G.I.), and potentially eligible reports were retrieved and scrutinized in full text. Divergences were resolved by discussion and consultation with a fourth investigator (G.G.). The fullsize articles published in peer-reviewed journals were considered for this meta-analysis.

Prospective and retrospective observational studies were included if they met the following pre-specified criteria: (I) inclusion of patients hospitalized for COVID-19; (II) data on in-hospital mortality; (III) data on baseline cardiovascular risk factors. Studies reporting only surrogate outcome measures or with largely incomplete data on in-hospital outcome were excluded. Studies reporting data on special populations (e.g. pregnant women, children) were excluded. For papers collecting overlapping data, only studies with the largest number of patients were selected. In some doubtful cases, corresponding authors were contacted for requests for clarifications.

\section{Data extraction and quality assessment}

Two investigators (A.S. and L.E.) independently extracted data by using an agreed predefined spreadsheets reporting first author, journal, year of publication, study design, region and country, period of enrollment, sample size, in-hospital mortality, demographic and clinical cardiovascular risk factors (age, male gender, hypertension, diabetes and smoking). Data on the severity of the disease expressed by the percentage of acute respiratory distress syndrome (ARDS) and of invasive mechanical ventilation (IMV) use, as well as data on clinical setting expressed by the percentage of admission in intensive care unit (ICU) 
were collected. Disagreements were resolved by consensus among all the investigators.

Two unmasked reviewers (L.E., G.I.) evaluated the quality of the studies on pre-specified electronic forms according to the Newcastle-Ottawa scale items. The reviewers independently appraised study selection, comparability, and outcome of each report, and divergences were resolved after consensus.

\section{Study outcome}

The study outcome measure was the occurrence of death during hospitalization.

\section{Data synthesis and analysis}

The meta-analysis was performed by estimating the mean in-hospital mortality over all studies using random effects models with restricted maximum-likelihood estimator. Random-effects model was preferred for estimating the average effect and its precision, which would give a more conservative estimate of the $95 \%$ confidence interval $(\mathrm{CI})$, due to the heterogeneity within and between studies. Studies with larger sample size and therefore a smaller standard error received more weight when calculating the mean survival proportions. The individual study proportions of outcomes were converted using the Freeman-Tukey double arcsine transformation method before the pooled analysis. The summarized proportions in the original scales were calculated as the back-transformation of the arcsine transformed estimates. Raw data on the prevalence of cardiovascular risk factors were collected for each study included in this meta-analysis.

Multiple univariable meta-regression analyses were performed to appraise the possible association between the proportion of single cardiovascular risk factors and the risk of death, as well as the degree of heterogeneity among studies. In order to assess whether the associations resulted at univariable analyses were age-independent, data on each cardiovascular risk factor were entered in age-adjusted multivariable meta-regression models.

These analyses were performed using the logarithmic transformation of the proportions, then back transformed through the exponential function.

To appraise for the influence of clinical setting on the study outcome, we conducted a subgroup analysis for studies including only ICU patients versus studies enrolling mixed population (both ward and ICU) and tested any interaction between subgroups.

The hypothesis of statistical heterogeneity was tested by means of Cochran $Q$ statistic and the null hypothesis of statistical homogeneity was refused if $\mathrm{p}$ values were less than 0.10 . I [2] values $<40 \%, 40-60 \%$ and $>60 \%$ indicated low, moderate, and substantial statistical inconsistency, respectively. [14] Funnel plots for the primary outcome were used to evaluate the presence of publication bias, heterogeneity of studies, or data irregularities. The significance of asymmetry was explored using visual inspection tested by a rank correlation test based on Kendall's $\tau$. All analyses were performed using R version 3.5.1 (R Foundation for Statistical Computing, Vienna, Austria).

\section{Results}

Of 12,038 reports initially identified, we retrieved 8,514 studies through merging of data from independent searches and removing duplicates. Sixteen studies have been excluded because of overlapping populations. During screening and eligibility assessment, we identified 45 full-size articles enrolling 18,300 patients. [7-11, 15-54] The baseline features of the study populations, where available, are reported in Table 1 and Additional file 1 . The study selection process is depicted in Fig. 1.

The pooled estimate of in-hospital mortality was $12 \%$ (95\% CI 9-15\%) although affected by a high heterogeneity degree among studies $\left(\mathrm{I}^{2}: 96.5 \%\right.$; $\mathrm{p}<0.001$; Fig. 2$)$. ARDS was reported in $27 \%$ of cases $(95 \%$ CI $14-42 \%$; Fig. 2) and significantly correlated with the rate of death across reports (coefficient: 1.02; 95\% CI 1.01-1.03; $\mathrm{p}<0.001$; Fig. 3). Moreover, the proportion of IMV use, another index of COVID-19 severity, was significantly higher among studies reporting a higher incidence of inhospital mortality (coefficient: 1.02; 95\% CI 1.01-1.02; $\mathrm{p}<0.001$; Fig. 3).

Data on clinical setting were available in 19 studies (Fig. 3). Seven studies were conducted exclusively on ICU patients; the remaining studies enrolled mixed populations (both ICU and ward) with a mean proportion of patients admitted in ICU of $14.6 \%$ (95\% CI 9.0-21.2\%). The risk of in-hospital death was significantly higher in the studies restricted to the ICU setting (25\%, 95\% CI $14-38 \%)$ as compared to the mixed cohorts $(9 \%, 95 \% \mathrm{CI}$ $5-15 \% ; P_{\text {interaction }}=0.004$ ).

The univariable meta-regression analyses between cardiovascular risk factors and in-hospital mortality are displayed in Fig. 4 and Table 2. Age was available in all the studies and resulted significantly associated with inhospital mortality (coefficient: 1.06; 95\% CI 1.04-1.09; $\mathrm{p}<0.001$ ). Diabetes was reported in 43 of 45 studies and resulted significantly associated with the study outcome (coefficient: 1.04; 95\% CI 1.02-1.07; p < 0.001). Hypertension was available in 42 of 45 studies and significantly correlated with in-hospital mortality (coefficient: 1.01; 95\% CI 1.01-1.03; $\mathrm{p}=0.013$ ). Male sex (coefficient: 1.01; 95\% CI 0.99-1.03; $\mathrm{p}=0.197$ ) and smoking (coefficient: 1.01; 95\% CI $0.98-1.04 ; \mathrm{p}=0.653$ ) did not show significant associations with fatal outcome. 
Table 1 Studies included in the meta-analysis

\begin{tabular}{|c|c|c|c|c|c|}
\hline Author & Journal & Region, country & Time of enrollment & End of follow-up & Patients, $\mathrm{N}$ \\
\hline Arentz M & JAMA & Washington State, US & $\begin{array}{l}\text { From February 20, } 2020 \text { to March } \\
5,2020\end{array}$ & March 17, 2020 & 21 \\
\hline Barrasa H & Am J Respir Crit Care Med & Basque country, Spain & $\begin{array}{l}\text { From March 4, } 2020 \text { to March } \\
\text { 31, } 2020\end{array}$ & March 31, 2020 & 48 \\
\hline Bhatraju K & N Eng J Med & Washington State, US & $\begin{array}{l}\text { From December 24, } 2019 \text { to } \\
\text { March 9, } 2020\end{array}$ & March 23, 2020 & 24 \\
\hline Cai Q & Allergy & Guangdong, China & $\begin{array}{l}\text { From January 11, } 2020 \text { to Febru- } \\
\text { ary } 6,2020\end{array}$ & March 6, 2020 & 298 \\
\hline Chen G & J Clin Invest & Hubei, China & $\begin{array}{l}\text { From December } 30,2019 \text { to } \\
\quad \text { January } 27,2020\end{array}$ & February 2, 2020 & 21 \\
\hline Chen N & Lancet & Hubei, China & $\begin{array}{l}\text { From January 1, } 2020 \text { to January } \\
20,2020\end{array}$ & January 25, 2020 & 99 \\
\hline Cheng $Y$ & Kidney Int & Hubei, China & $\begin{array}{l}\text { From January } 28,2020 \text { to Febru- } \\
\text { ary } 11,2020\end{array}$ & February 29, 2020 & 701 \\
\hline Cuil & J Thromb Haemost & Hubei, China & $\begin{array}{l}\text { From January 30, } 2020 \text { to March } \\
22,2020\end{array}$ & March 22, 2020 & 81 \\
\hline Du R & Eur Respir J & Hubei, China & $\begin{array}{l}\text { From December } 25,2019 \text { to } \\
\quad \text { February } 7,2020\end{array}$ & March 24, 2020 & 179 \\
\hline Feng $Y$ & Am J Respir Crit Care Med & 3 provinces, China & $\begin{array}{l}\text { From January 1, } 2020 \text { to Febru- } \\
\text { ary 15, } 2020\end{array}$ & March 21, 2020 & 476 \\
\hline Goyal P & N Eng J Med & New York, US & $\begin{array}{l}\text { From March 5, } 2020 \text { to March } \\
272020\end{array}$ & April 10, 2020 & 393 \\
\hline Grasselli G & JAMA & Lombardia, Italy & $\begin{array}{l}\text { From February 20, } 2020 \text { to March } \\
\quad 18,2020\end{array}$ & March 25, 2020 & 1591 \\
\hline Grein J & N Eng J Med & Canada, Europe, Japan and US & $\begin{array}{l}\text { From January 25, } 2020 \text { to March } \\
\quad 7,2020\end{array}$ & March 7, 2020 & 53 \\
\hline Guan W & Eur Respir J & 31 provinces, China & $\begin{array}{l}\text { From December } 11,2020 \text { to } \\
\text { January } 31,2020\end{array}$ & January 31, 2020 & 1590 \\
\hline GuoT & JAMA Cardiol & Hubei, China & $\begin{array}{l}\text { From January } 23,2020 \text { to Febru- } \\
\text { ary } 23,2020\end{array}$ & February 23, 2020 & 187 \\
\hline Guo W & Diabetes Metab Res Rev & Hubei, China & $\begin{array}{l}\text { From February } 10,2020 \text { to Feb- } \\
\text { ruary } 29,2020\end{array}$ & March 3, 2020 & 174 \\
\hline $\operatorname{Han} Y$ & J Med Virol & Shaanxi, China & $\begin{array}{l}\text { From January } 31,2020 \text { to Febru- } \\
\text { ary } 16,2020\end{array}$ & February 16, 2020 & $25^{\mathrm{a}}$ \\
\hline $\mathrm{HeY}$ & Infect Control Hosp Epidemiol & Hubei, China & $\begin{array}{l}\text { From December 30, } 2019 \text { to } \\
\text { February 29, } 2020\end{array}$ & February 29, 2020 & 65 \\
\hline Huang $C$ & Lancet & Hubei, China & $\begin{array}{l}\text { From December 16, } 2019 \text { to } \\
\text { January 2,2020 }\end{array}$ & January 22, 2020 & 41 \\
\hline $\operatorname{Jin} X$ & Gut & Zhejiang, China & $\begin{array}{l}\text { From January } 17,2020 \text { to Febru- } \\
\text { ary } 8,2020\end{array}$ & February 9, 2020 & 74 \\
\hline Li J & JAMA Cardiol & Hubei, China & $\begin{array}{l}\text { From January } 15,2020 \text { to March } \\
\quad 15,2020\end{array}$ & March 15, 2020 & 1178 \\
\hline LiR & J Clin Virol & Hubei, China & $\begin{array}{l}\text { From January 20, } 2020 \text { to Febru- } \\
\text { ary } 14,2020\end{array}$ & February 29, 2020 & 225 \\
\hline Liu K & $J$ Infect & Hainan, China & $\begin{array}{l}\text { From January } 15,2020 \text { to Febru- } \\
\text { ary } 18,2020\end{array}$ & February 18, 2020 & 56 \\
\hline Liu K & Chin Med J & $\begin{array}{l}9 \text { tertiary hospitals in Hubei, } \\
\text { China }\end{array}$ & $\begin{array}{l}\text { From December } 30,2019 \text { to } \\
\quad \text { January } 24,2020\end{array}$ & January 24, 2020 & 137 \\
\hline Liu W & Chin Med J & Hubei, China & $\begin{array}{l}\text { From December 30, } 2020 \text { to } \\
\text { January 15, } 2020\end{array}$ & January 15, 2020 & 78 \\
\hline LiuY & Platelets & Hubei, China & $\begin{array}{l}\text { From January 2, } 2020 \text { to March } \\
\quad \text { 1,2020 }\end{array}$ & March 1, 2020 & 383 \\
\hline McMichael TM & N Eng J Med & Washington State, US & $\begin{array}{l}\text { From February 27, } 2020 \text { to March } \\
\quad 18,2020\end{array}$ & March 18, 2020 & $101^{b}$ \\
\hline Myers L & JAMA & California, US & $\begin{array}{l}\text { From March 1, } 2020 \text { to March } \\
\text { 31, } 2020\end{array}$ & April 9, 2020 & 377 \\
\hline
\end{tabular}


Table 1 (continued)

\begin{tabular}{|c|c|c|c|c|c|}
\hline Author & Journal & Region, country & Time of enrollment & End of follow-up & Patients, N \\
\hline Richardson S & JAMA & New York, US & $\begin{array}{l}\text { From March 1, } 2020 \text { to April 4, } \\
2020\end{array}$ & April 4, 2020 & 5700 \\
\hline Shi H & Lancet Infect Dis & Hubei, China & $\begin{array}{l}\text { From December 20, } 2019 \text { to } \\
\text { January } 23,2020\end{array}$ & February 8, 2020 & 81 \\
\hline Shi S & JAMA Cardiol & Hubei, China & $\begin{array}{l}\text { From January } 20,2020 \text { to Febru- } \\
\text { ary } 10,2020\end{array}$ & February 15, 2020 & 416 \\
\hline Simonnet A & Obesity (Silver Spring) & Hauts-de-France, France & $\begin{array}{l}\text { From February 27, } 2020 \text { to April } \\
5,2020\end{array}$ & April 6, 2020 & 124 \\
\hline $\operatorname{Tan} C$ & J Med Virol & Hunan, China & $\begin{array}{l}\text { From January } 18,2020 \text { to Febru- } \\
\text { ary } 10,2020\end{array}$ & February 20, 2020 & 27 \\
\hline Tang N & J Thromb Haemost & Hubei, China & $\begin{array}{l}\text { From January 1, } 2020 \text { to Febru- } \\
\text { ary } 13,2020\end{array}$ & March 13, 2020 & 449 \\
\hline Wang L & $J$ Infect & Hubei, China & $\begin{array}{l}\text { From January 1, } 2020 \text { to Febru- } \\
\text { ary 6, } 2020\end{array}$ & March 5, 2020 & 339 \\
\hline Wang Z & Clin Infect Dis & Hubei, China & $\begin{array}{l}\text { From January } 16,2020 \text { to Janu- } \\
\text { ary } 29,2020\end{array}$ & February 4, 2020 & 69 \\
\hline WuC & JAMA Intern Med & Hubei, China & $\begin{array}{l}\text { From December 25, } 2019 \text { to } \\
\text { January } 26,2020\end{array}$ & February 13, 2020 & 201 \\
\hline Xu B & $J$ Infect & Hubei, China & $\begin{array}{l}\text { From December 26, } 2019 \text { to } \\
\text { March 1,2020 }\end{array}$ & March 5, 2020 & 187 \\
\hline Yuan M & PLoS One & Hubei, China & $\begin{array}{l}\text { From January } 1,2020 \text { to January } \\
25,2020\end{array}$ & January 25, 2020 & 27 \\
\hline Zha L & Med J Aust & Anhui, China & $\begin{array}{l}\text { From January } 24,2020 \text { to Febru- } \\
\text { ary } 24,2020\end{array}$ & February 29, 2020 & 31 \\
\hline Zhang J & Allergy & Hubei, China & $\begin{array}{l}\text { From December } 29,2020 \text { to } \\
\text { February } 16,2020\end{array}$ & February 28, 2020 & 290 \\
\hline Zhang L & J Thromb Haemost & Hubei, China & $\begin{array}{l}\text { From January 12, } 2020 \text { to March } \\
15,2020\end{array}$ & March 15, 2020 & 343 \\
\hline Zhang P & Circ Res & Hubei, China & $\begin{array}{l}\text { From December 31, } 2019 \text { to } \\
\text { February 20,2020 }\end{array}$ & March 7, 2020 & 1128 \\
\hline Zhou F & Lancet & Hubei, China & $\begin{array}{l}\text { From December } 29,2019 \text { to } \\
\text { January } 31,2020\end{array}$ & January 31, 2020 & 191 \\
\hline ZhouY & Clin Transl Sci & Hubei, China & $\begin{array}{l}\text { From January } 28,2020 \text { to March } \\
\quad 02,2020\end{array}$ & March 02, 2020 & 21 \\
\hline
\end{tabular}

US United States

a Only adult patients were considered in the present meta-analysis

b This study was conducted in a nursing facility. Only residents infected by SARS-CoV-2 were included in the present meta-analysis

At multivariable age-adjusted meta-regression analysis, diabetes was significantly associated with in-hospital mortality (coefficient: 1.02; 95\% CI 1.01-1.05; $\mathrm{p}=0.043$ ); conversely, hypertension was no longer significant after adjustment for age (coefficient: 1.00; 95\% CI 0.99-1.01; $\mathrm{p}=0.820$; Table 2). A significant association between age and the study outcome was confirmed in each of the multivariable models.

\section{Quality assessment and publication bias}

Quality assessment is detailed in Additional file 2. All the included studies showed an adequate-to-good quality. Thirty-two of 45 studies showed scores $\geq 6$ according to the Newcastle-Ottawa scale; a score of 5 was observed in the remaining 13.
Visual inspection of funnel plots and the rank correlation test showed no significant asymmetry (Kendall's tau $=-0.575, \mathrm{p}=0.565)$, suggesting that in-hospital mortality did not depend on the size of the studies (Fig. 5).

\section{Discussion}

The search for potential associations between patient characteristics and outcome may be helpful to stratify prognosis, to plan patient clinical management and to optimize sources in COVID-19 outbreak. Although many cardiovascular risk factors have been associated with adverse outcome, confounding and residual confounding could lead to apparent associations that might not represent genuine effects or can bias the magnitudes of effects. This hazard is higher in small series, single-centre (and 


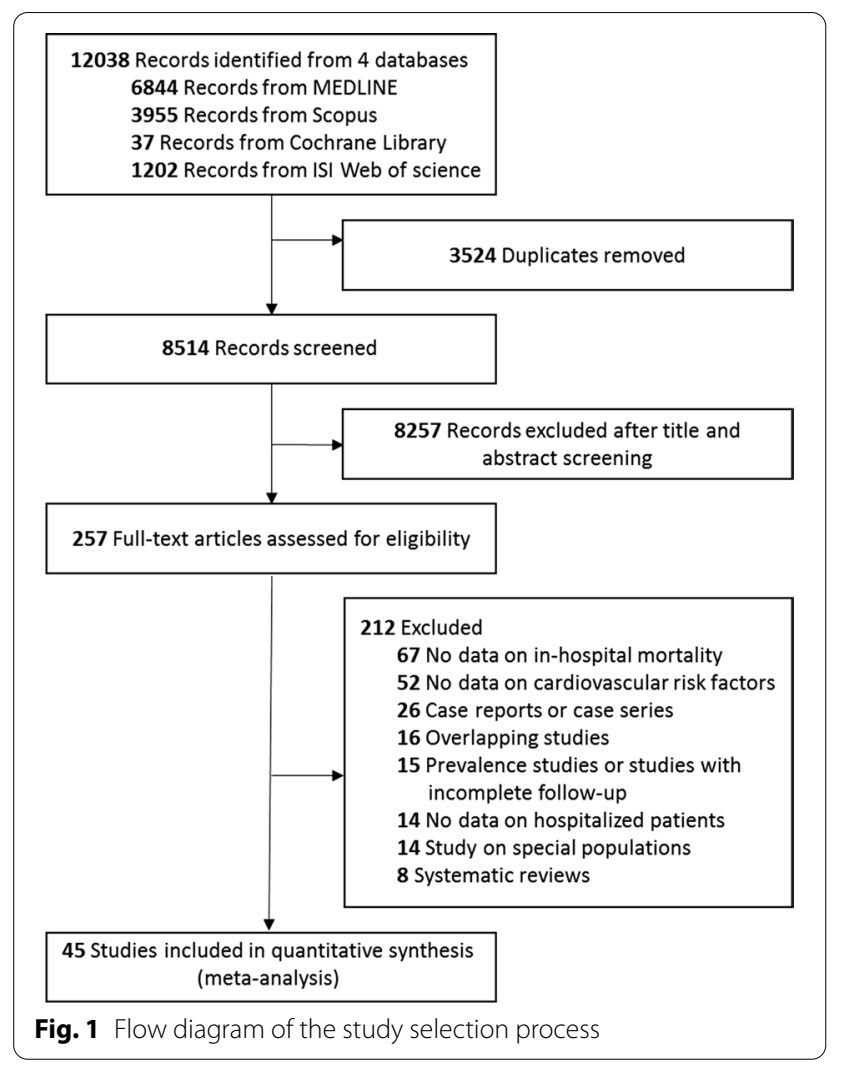

single-country) studies, and selective reports from special populations. [55].

By including 45 studies and 18,300 patients, this is the largest meta-analysis investigating the effect of cardiovascular risk factors on in-hospital mortality in COVID19 , by using crude and multivariable meta-regression models, available so far. The main findings of this study can be summarized as follows: (I) COVID-19 was associated to a high risk of in-hospital death, which occurred in about one patient in 8; (II) studies with high percentage of ARDS and IMV use, two indexes of disease severity, as well as of ICU admission, reported the highest risk of death during hospitalization; (III) age and diabetes were independent predictors of mortality; (IV) after adjustment for age, hypertension did not show any significant association with the risk of in-hospital death.

The mortality estimate of COVID-19 in the general population depends on the number of deaths relative to the number of confirmed cases of infection, which is not representative of the actual death rate, and may be substantially overestimated. [56, 57] Real-world studies conducted on inpatient populations have the advantage to provide the real proportion of mortality among subjects with confirmed COVID-19 diagnosis. The overall incidence of death detected in this analysis was clearly high, emphasizing the hazard of COVID-19 in patients who required hospitalization. These results were consistent with a recent meta-analysis by Sabatino et al., which included 21 studies reporting clinical data on hospitalized patients infected by SARS-CoV-2. They found a fatality rate of $9.6 \%$, with large heterogeneity among studies, and reported a significant association of age and pre-existing cardiovascular risk factors with the risk of in-hospital mortality at univariable meta-regression analysis. [58].

The pooled mortality estimate in our analysis was affected by a wide inconsistency between patient cohorts. There are many reasons for the effect variability detected across observational studies including clinical setting (ICU, ward), the prevalence of in-hospital complications (e.g. ARDS) and the need of invasive mechanical supportive measures, which may play as effect modifiers. We tried to account for this variability by performing exploratory analyses of the relationships between the rate of mortality and the proportion of ARDS and IMV use, which are indexes of disease severity. As expected, the higher the percentage of ARDS/IMV among patients enrolled, themm higher was the rate of death during in-hospital course. In addition, the subgroup including only studies conducted in ICU, compared to the mixed group, showed a significantly higher risk of death. These analyses were still affected by high residual heterogeneity suggesting that these variables, although able to stratify prognosis, could not account for the differences among the studies included in this meta-analysis. Our analysis could not account for multiple variables as well as for concealed confounders such as the availability of healthcare resources, in-hospital paths, healthcare systems and strategies adopted in the context of pandemic between centers or countries. [4] Actually, high inconsistency is a frequent finding in meta-analyses of observational studies and should be weighed against inference statistics considerations. If the goal of a meta-analysis is to evaluate the direction of a possible association, as in our study, its results can be acceptable despite a certain inconsistency among studies. [59].

The association of age with mortality is an expected finding; noteworthy, this significant correlation persisted in multiple adjusted meta-regression models including other cardiovascular risk factors. This result underlies the importance of individual preventive and protective measures during COVID-19 public health crisis and of dedicated healthcare strategies for elderly patients during hospitalization.

Diabetes is the second most common comorbidity (after hypertension) in hospitalized patients with COVID-19, and its prevalence increase with age. [7, 26, 60] Our analysis showed that diabetic patients infected by SARS-CoV-2, as compared to those without diabetes, 


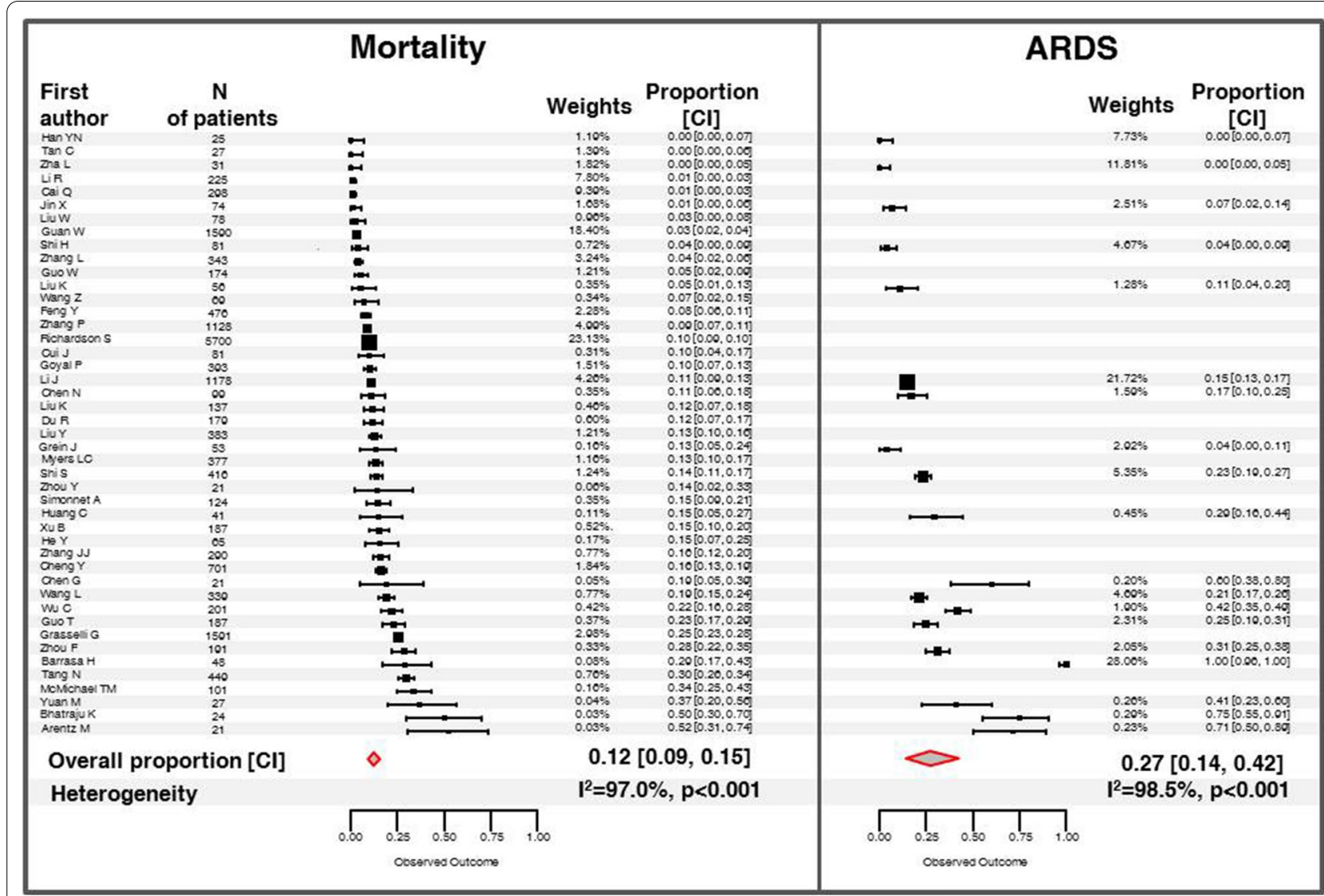

Fig. 2 Individual and overall incidence for in-hospital mortality and ARDS. Solid squares indicate the weighted estimate of incidence for each single study; horizontal bars indicate $95 \% \mathrm{Cl}$; red diamond indicates the overall estimated incidence

have an higher risk for in-hospital death independently from age. Beyond the inherent association of diabetes with atherosclerosis and cardiovascular disease, bad glycemic control may negatively affect the outcome of patients with diabetes infected by SARS-CoV-2 through different mechanisms [61]: corticosteroid therapy, high glucose level related to septic status, inadequate glucose monitoring in patients with infection, lack of contact with healthcare professional qualified on diabetes management, and angiotensin-converting enzyme inhibitors (ACEi) withdrawal.

SARS-CoV-2 binds to the zinc peptidase angiotensin-converting enzyme 2 (ACE2), a surface molecule expressed by endothelial cells of arteries and veins, arterial smooth muscle, epithelial cells, and immune cells. [62] Some authors hypothesized a relationship between diabetes and virulence of SARS-CoV-2 infection, since hyperglycemia might favor virus entrance into immune cells by increasing the expression of ACE2.

Our study demonstrates that the association between hypertension and mortality in hospitalized patients with COVID-19 reflect largely the older age of these patients. In fact, the significant correlation observed at the univariable meta-regression model was not confirmed after adjustment for age. Preliminary studies suggested that hypertension was a risk factor for inhospital outcome in patients with COVID-19. [7, 10, $26,60]$ Based on these findings, some authors hypothesized that ACEi or angiotensin II receptor blockers (ARBs) might increase the expression of ACE2 in animal models and facilitate virus entry into the host cells. [63] However, these studies reported only descriptive or univariable regression analyses, not accounting for potential confounders, and did not demonstrate an independent association between hypertension and fatal outcome. Actually, a recent multi-center propensity-score matching study on 1,128 COVID-19 patients with hypertension showed a significantly lower risk of 28-day all-cause mortality and of septic shock in ACEi/ ARBs group versus non-ACEi/ARBs [52]. This finding was confirmed in a recent study on 8,910 from 169 hospital, which showed that no risk of in-hospital death was associated with the use of ACEi/ARBs at multivariable analysis [64]. 


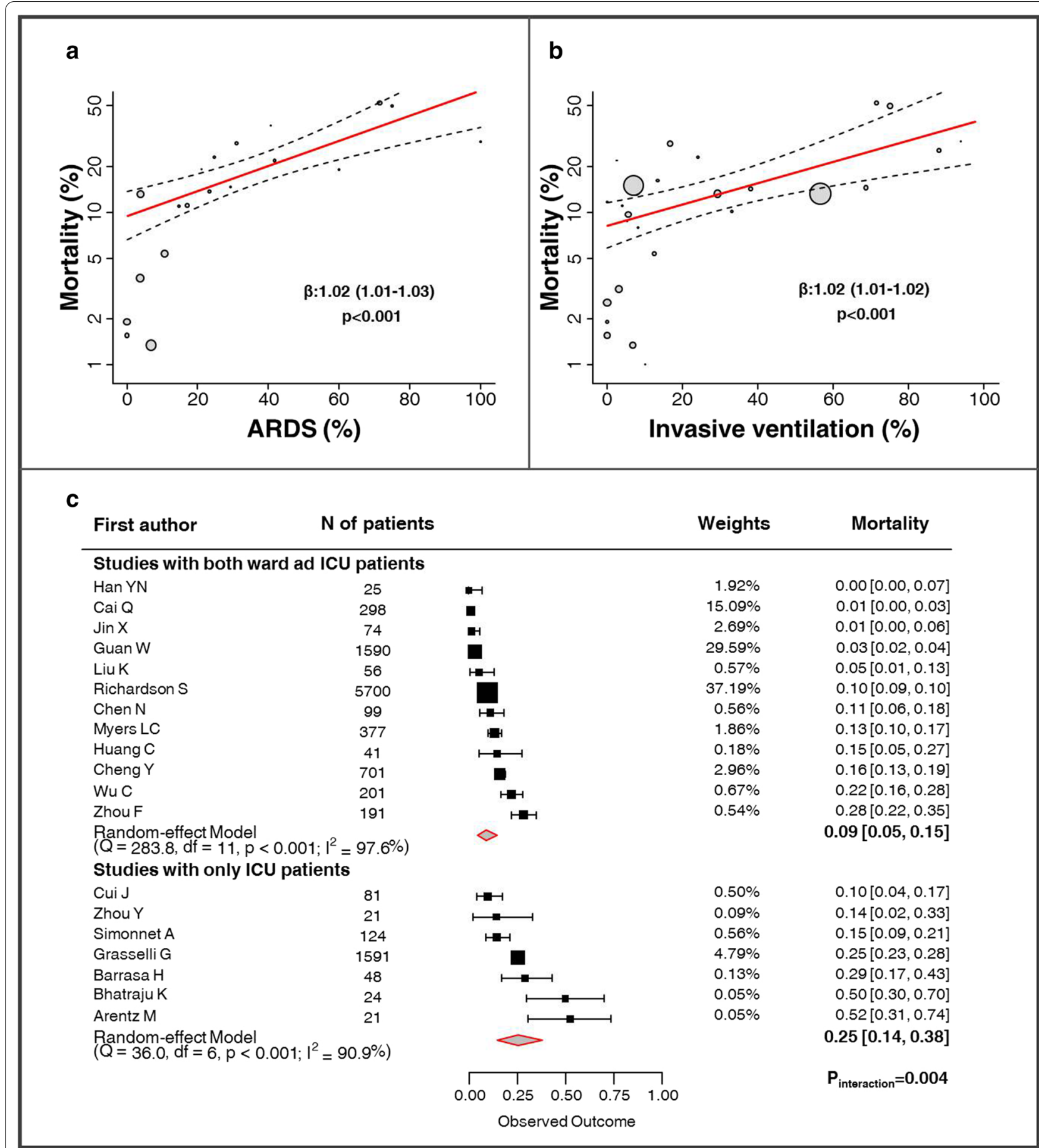

Fig. 3 Exploratory analyses for the effects of ARDS, IMV and ICU on in-hospital mortality. Scatter plots showing the association between the proportion of ARDS and IMV use and in-hospital mortality $(\mathbf{a}, \mathbf{b})$. Each circle size represents a study, telescoped by its weight in the analysis. The $x$-axis shows the prevalence of each covariate. The $y$-axis shows the incidence of in-hospital mortality. The regression line is calculated by the univariable meta-regression model. Subgroup analysis for studies including only ICU patients versus studies enrolling mixed population (both ward and ICU; $\mathbf{c}$ ). Solid squares indicate the weighted estimate of incidence for each single study; horizontal bars indicate $95 \%$ Cl; red diamond indicates the overall estimated incidence. ARDS acute respiratory distress syndrome, ICU intensive care unit, IMV invasive mechanical ventilation 


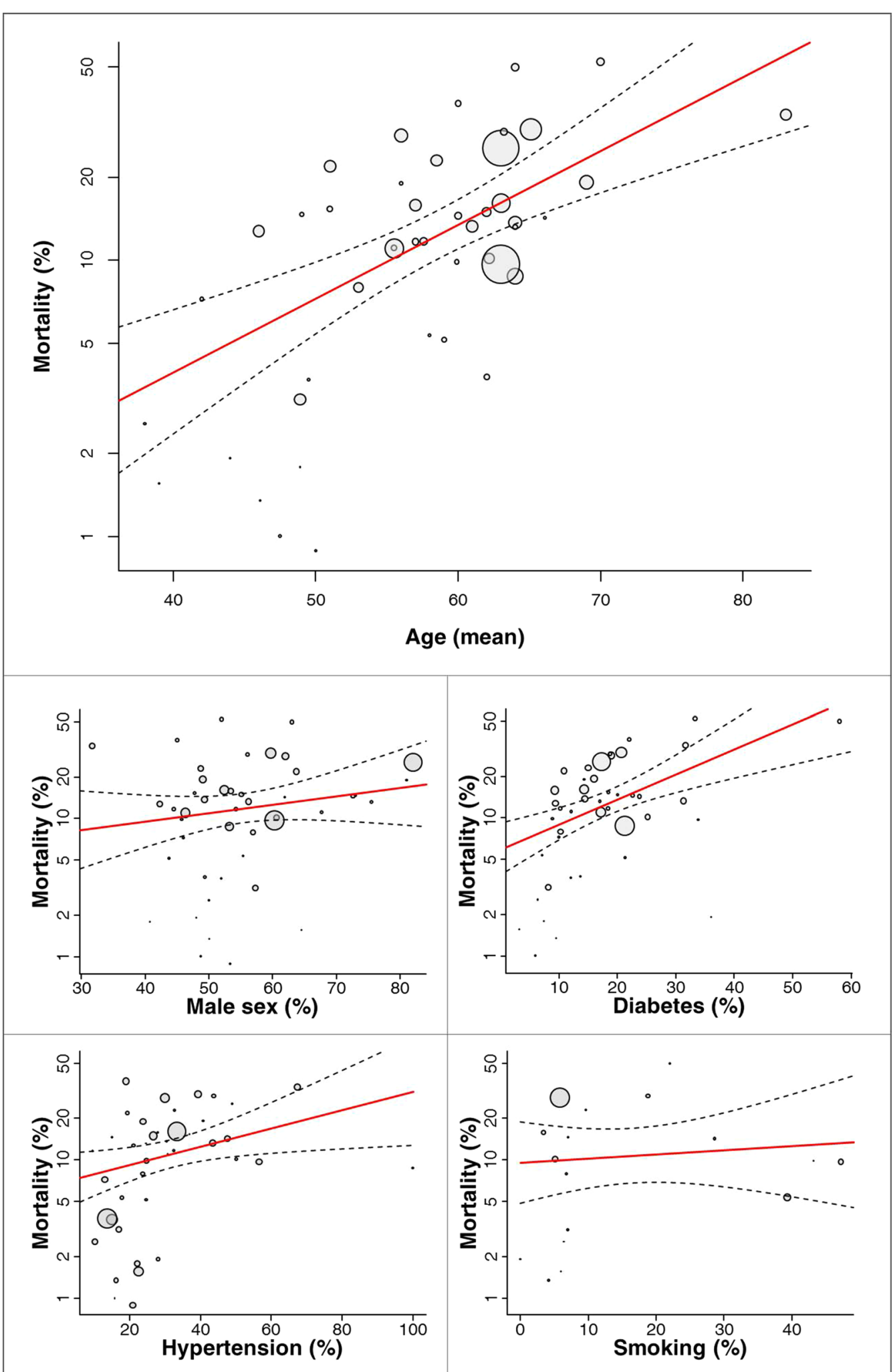

Fig. 4 Meta-Regression analysis of the effects of cardiovascular risk factors on in-hospital mortality. Scatter plots showing the association between cardiovascular risk factors and in-hospital mortality. Each circle size represents a study, telescoped by its weight in the analysis. The $x$-axis shows the prevalence of each covariate. The $y$-axis shows the incidence of in-hospital mortality. The regression line is calculated by the univariable meta-regression model 
Table 2 Univariable and multivariable meta-regression analyses of the effects of cardiovascular risk factors on in-hospital mortality

\begin{tabular}{|c|c|c|c|c|c|c|}
\hline \multicolumn{4}{|c|}{ Univariable analysis } & \multicolumn{3}{|c|}{ Multivariable analysis } \\
\hline Variable & Coefficient & {$[\mathrm{Cl}]$} & $p$ value & Variables & Coefficient & {$[\mathrm{Cl}]$} \\
\hline \multirow[t]{2}{*}{ Age } & 1.061 & {$[1.037,1.086]$} & $<0.001$ & - & - & - \\
\hline & & & & - & - & - \\
\hline \multirow[t]{2}{*}{ Male sex } & 1.012 & {$[0.994,1.031]$} & 0.1967 & Male sex & 1.015 & {$[0.998,1.033]$} \\
\hline & & & & Age & 1.063 & {$[1.039,1.088]$} \\
\hline \multirow[t]{2}{*}{ Hypertension } & 1.014 & {$[1.003,1.025]$} & 0.0133 & Hypertension & 0.999 & {$[0.986,1.011]$} \\
\hline & & & & Age & 1.056 & {$[1.025,1.087]$} \\
\hline \multirow[t]{2}{*}{ Diabetes } & 1.043 & {$[1.021,1.065]$} & $<0.001$ & Diabetes & 1.024 & {$[1.001,1.047]$} \\
\hline & & & & Age & 1.042 & {$[1.013,1.071]$} \\
\hline \multirow[t]{2}{*}{ Smoking } & 1.007 & {$[0.977,1.036]$} & 0.6534 & Smoking & 0.977 & {$[0.950,1.004]$} \\
\hline & & & & Age & 1.120 & {$[1.056,1.189]$} \\
\hline
\end{tabular}

Cl confidence interval

The association between smoking and mortality in COVID-19, though plausible, is still debated $[65,66]$. A recent study by Williamson and colleagues on 17,278,392 adults from the OpenSAFELY platform, showed that current smokers were also associated with a lower risk of mortality related to COVID-19 [HR: 0.89 (0.82-0.97)]

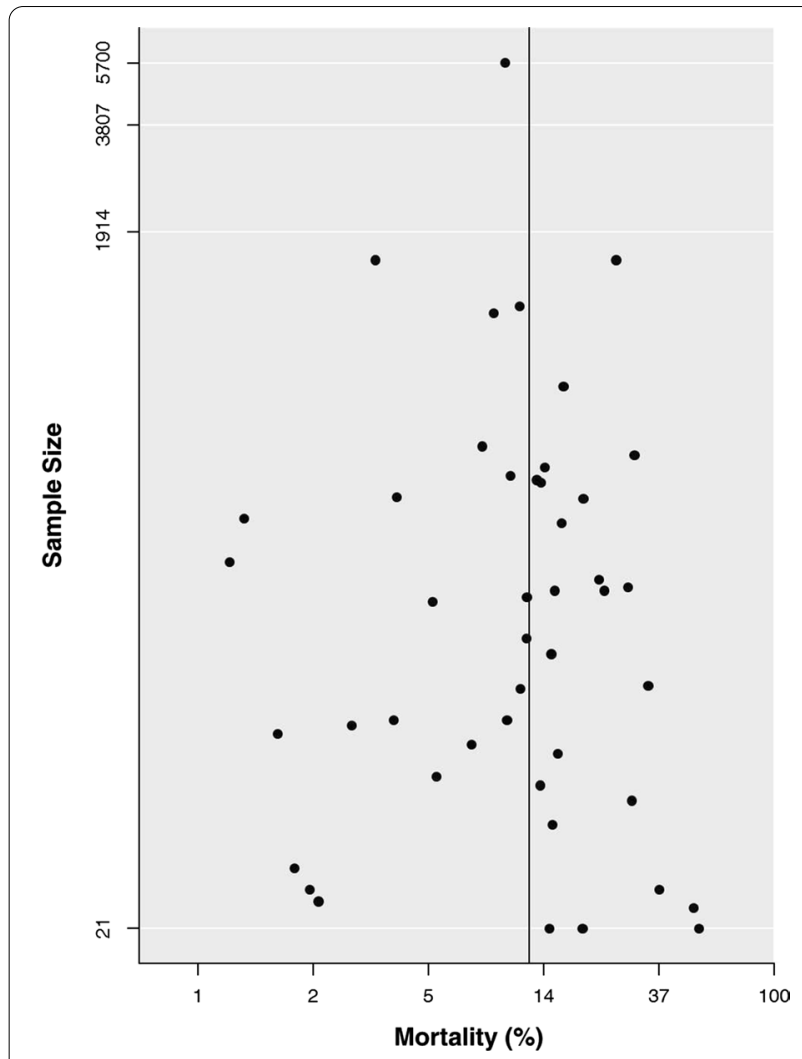

Fig. 5 Funnel plot for in-hospital mortality. The analysis showed no asymmetry suggestive for a significant risk of publication bias compared to never smokers [67]. In that analysis, the hazard ratio could not be interpreted causally owing to the inclusion of factors that were likely to mediate smoking effects (e.g. the association was no longer significant after adjustment for COPD). Thus, whether smoking is associated with higher risk of mortality need to be clarified in future studies as the epidemic progresses and more data accumulate.

The recent onset and the variable dissemination pattern of the outbreak make difficult to draw firm conclusions on the clinical characteristics and epidemiology of COVID-19. Our data indicate that elderly and diabetic patients are higher-risk populations, and suggest taking utmost care in clinical management of these patients during hospitalization.

Continuous surveillance, with reporting of patient characteristics worldwide, are required to confirm our findings and more deeply understand the relationship between cardiovascular risk factors and outcome of patients infected by SARS-CoV-2.

\section{Study limitations}

Some limitations of our study should be acknowledged. Although we included 45 studies enrolling 18,300 patients, results of meta-analyses are hypothesis-generating and should be interpreted accordingly.

The observational nature of the studies included might have contributed to the heterogeneity observed in this analysis. We tried to manage this issue by performing univariable meta-regressions for ARDS and IMV as well as a subgroup analysis for ICU vs ICU/ward. Although these analyses showed significant and clinically valuable results, they were still affected by a substantial residual heterogeneity. 
Owing to the intrinsic limitations of study-level analyses, we could not account for multiple potential confounders and we adjusted only for age, considered the most important confounding factor in this clinical setting. Moreover, we could not adjust for hidden confounders as well as for patient characteristics nonsystematically or rarely reported.

Many authors reported incomplete clinical and instrumental information (i.e. prevalence of coronary heart disease, heart failure, chronic kidney disease, left ventricular ejection fraction, etc.) due to factors such as critically ill patients, operator's fear of contagion, and in-hospital paths. We may hypothesize that difficulties in data collection/storage and limited feasibility/repeatability of instrumental exams may have affected the completion and granularity of data.

To meet the urgent need of clinical reports on COVID19, many studies encompassed a relatively short followup time as compared to the course of the disease, and some of them ended before the discharge or death of each patients enrolled. Although we tried to manage this issue by excluding the studies with higher number of open cases at the end, a certain underestimation of mortality is likely. We do not claim to provide the exact estimate of in-hospital mortality in COVID-19 pandemic, but to explore the potential association between cardiovascular risk factors and outcome. Since the number of pandemicfocused studies is increasing, and clinical observation of these patients is ongoing, the current mortality pattern might change to some extent in the next weeks or months.

The majority of studies included in this analysis reported data from Chinese populations, and only ten reports were from other countries (3 from Europe and 7 from US). This issue might have affected the generalizability of our findings, and requires confirmation by large worldwide studies.

Among the cardiovascular risk factors, we did not analyze unfrequently reported conditions such as obesity, dyslipidemia, and family history of cardiovascular disease. Indeed, these data were seldom reported in the items selected for this meta-analysis, and were not sufficient for inference analysis.

\section{Conclusions}

This study suggests that older age and diabetes are associated to higher risk of in-hospital mortality in patients infected by SARS-CoV-2. Conversely, hypertension, male sex and smoking did not independently correlate with fatal outcome at multivariable meta-regression analysis.

Although difficult to realize in a pandemic scenario, large multicenter cross-national studies are warranted to improve our understanding on the association between cardiovascular risk factors and mortality in COVID-19.

\section{Supplementary Information}

The online version contains supplementary material available at https://doi. org/10.1186/s12872-020-01816-3.

Additional file 1: Main characteristics of the studies included in the analysis.

Additional file 2: Quality assessment of the studies based on the Newcastle-Ottawa scale.

\section{Abbreviations}

ACE2: Angiotensin-converting enzyme 2; ACEi: Angiotensin-converting enzyme inhibitors; ARBs: Angiotensin II receptor blockers; ARDS: Acute respiratory distress syndrome; $\mathrm{Cl}$ : Confidence interval; COVID-19: Coronavirus disease 2019; ICU: Intensive care unit; IMV: Invasive mechanical ventilation; MOOSE: Meta-analysis of observational studies in epidemiology statement; SARSCoV-2: Severe acute respiratory syndrome coronavirus 2.

\section{Acknowledgments}

Not applicable.

\section{Authors' contributions}

A.S, M. DM, and G.G contributed to the conception and the design of the work. A.S and M. DM contributed to the analysis and interpretation of data and drafted the work. L.E, G.I and M.B contributed to the acquisition of data. R.C, C.B, G. DL, M. C, C.V and G.G revised the work. All authors read and approved the final manuscript.

\section{Funding}

Not applicable.

\section{Availability of data and materials}

All data generated or analyzed during this study are included in this published article (and its supplementary information files).

Ethics approval and consent to participate Not applicable.

Consent for publication

Not applicable.

Competing interests

The authors declare that they have no competing interests.

\section{Author details}

${ }^{1}$ Department of Medicine, Surgery and Dentistry, University of Salerno, Baronissi, Salerno, Italy. ${ }^{2}$ Division of Cardiology, Cardiovascular and Thoracic Department, University Hospital "San Giovanni di Dio e Ruggi d'Aragona", Salerno, Italy. ${ }^{3}$ Division of Cardiology, Azienda Ospedaliera-Universitaria "Maggiore della Carità", Eastern Piedmont University, Novara, Italy. ${ }^{4}$ Vascular Pathophysiology Unit, IRCCS Neuromed, Pozzilli, Isernia, Italy.

Received: 28 July 2020 Accepted: 8 December 2020 Published online: 07 January 2021

\section{References}

1. Zhu N, Zhang D, Wang W, Li X, Yang B, Song J, et al. A novel coronavirus from patients with pneumonia in China, 2019. N Engl J Med. 2020;382:727-33.

2. Cook DJ, Marshall JC, Fowler RA. Critical illness in patients with COVID-19: mounting an effective clinical and research response. Jama. 2020 [Epub ahead of print]. 
3. World Health Organization Coronavirus disease 2019 (COVID-19). Situation Report-141. https://www.who.int/docs/default-source/coronaviru se/situation-reports/20200609-covid-19-sitrep-141.pdf?sfvrsn=72fa1 b16_2. Accessed 10 June 2020.

4. Ji Y, Ma Z, Peppelenbosch MP, Pan Q. Potential association between COVID-19 mortality and health-care resource availability. Lancet Global Health. 2020;8:e480.

5. Onder G, Rezza G, Brusaferro S. Case-fatality rate and characteristics of patients dying in relation to COVID-19 in Italy. Jama. 2020 [Epub ahead of print].

6. Fanidi A, Jouven X, Gaye B. Strategies to control COVID-19 and future pandemics in Africa and around the globe. Eur Heart J. 2020 [Epub ahead of print].

7. Zhou F, Yu T, Du R, Fan G, Liu Y, Liu Z, et al. Clinical course and risk factors for mortality of adult inpatients with COVID-19 in Wuhan, China: a retrospective cohort study. Lancet. 2020;395:1054-62.

8. Guan WJ, Liang WH, Zhao Y, Liang HR, Chen ZS, Li YM, et al. Comorbidity and its impact on 1590 patients with Covid-19 in China: a nationwide analysis. Eur Respir J. 2020a;55:2000547.

9. Shi S, Qin M, Shen B, Cai Y, Liu T, Yang F, et al. Association of cardiac injury with mortality in hospitalized patients with COVID-19 in Wuhan, China. JAMA Cardiol. 2020 [Epub ahead of print].

10. Wu C, Chen X, Cai Y, Xia J, Zhou X, Xu S, et al. Risk factors associated with acute respiratory distress syndrome and death in patients with coronavirus disease 2019 Pneumonia in Wuhan, China. JAMA Int Med. 2020 [Epub ahead of print].

11. Huang C, Wang Y, Li X, Ren L, Zhao J, Hu Y, et al. Clinical features of patients infected with 2019 novel coronavirus in Wuhan, China. Lancet. 2020:395(10223):497-506.

12. Tzoulaki I, Elliott P, Kontis V, Ezzati M. Worldwide exposures to cardiovascular risk factors and associated health effects: current knowledge and data gaps. Circulation. 2016;133:2314-33.

13. Stroup DF, Berlin JA, Morton SC, Olkin I, Williamson GD, Rennie D, et al, Meta-analysis of observational studies in epidemiology: a proposal for reporting. Meta-analysis of observational studies in epidemiology (MOOSE) group. JAMA. 2000;283:2008-12.

14. Higgins JP, Thompson SG, Deeks JJ, Altman DG. Measuring inconsistency in meta-analyses. BMJ. 2003:327:557-60.

15. Arentz M, Yim E, Klaff L, Lokhandwala S, Riedo FX, Chong M, et al. Characteristics and outcomes of 21 critically III patients With COVID-19 in Washington State. Jama. 2020 [Epub ahead of print].

16. Barrasa H, Rello J, Tejada S, Martín A, Balziskueta G, Vinuesa C, et al. SARSCov-2 in Spanish intensive care: early experience with 15-day survival in Vitoria. Anaesth Crit Care Pain Med. 2020 [Epub ahead of print].

17. Bhatraju PK, Ghassemieh BJ, Nichols M, Kim R, Jerome KR, Nalla AK, et al. Covid-19 in critically III patients in the Seattle region-case series. N Engl J Med. 2020 [Epub ahead of print].

18. Cai Q, Huang D, Ou P, Yu H, Zhu Z, Xia Z, et al. COVID-19 in a Designated infectious diseases hospital outside Hubei Province, China. Allergy 2020 [Epub ahead of print].

19. Chen G, Wu D, Guo W, Cao Y, Huang D, Wang H, et al. Clinical and immunologic features in severe and moderate Coronavirus Disease 2019. J Clin Investig. 2020 [Epub ahead of print].

20. Chen N, Zhou M, Dong X, Qu J, Gong F, Han Y, et al. Epidemiological and clinical characteristics of 99 cases of 2019 novel coronavirus pneumonia in Wuhan, China: a descriptive study. Lancet. 2020;395:507-13.

21. Cheng $Y$, Luo R, Wang K, Zhang M, Wang Z, Dong L, et al. Kidney disease is associated with in-hospital death of patients with COVID-19. Kidney Int. 2020 [Epub ahead of print].

22. Cui S, Chen S, Li X, Liu S, Wang F. Prevalence of venous thromboembolism in patients with severe novel coronavirus pneumonia. J Thromb Haemost. 2020 [Epub ahead of print].

23. Du RH, Liang LR, Yang CQ, Wang W, Cao TZ, Li M, et al. Predictors of mortality for patients with COVID-19 pneumonia caused by SARS-CoV-2: a prospective cohort study. Eur Respir J. 2020 [Epub ahead of print].

24. Feng Y, Ling Y, Bai T, Xie Y, Huang J, Li J, et al. COVID-19 with different severity: a multi-center study of clinical features. Am J Respir Crit Care Med. 2020 [Epub ahead of print]

25. Goyal P, Choi JJ, Pinheiro LC, Schenck EJ, Chen R, Jabri A, et al. Clinical characteristics of covid-19 in New York City. N Engl J Med. 2020 [Epub ahead of print].
26. Grasselli G, Zangrillo A, Zanella A, Antonelli M, Cabrini L, Castelli A, et al. Baseline characteristics and outcomes of 1591 patients infected with SARS-CoV-2 admitted to ICUs of the Lombardy Region, Italy. Jama. 2020 [Epub ahead of print]

27. Grein J, Ohmagari N, Shin D, Diaz G, Asperges E, Castagna A, et al. Compassionate use of remdesivir for patients with severe covid-19. N Engl J Med. 2020 [Epub ahead of print].

28. Guo T, Fan Y, Chen M, Wu X, Zhang L, He T, et al. Cardiovascular implications of fatal outcomes of patients with coronavirus disease 2019 (COVID-19). JAMA Cardiol. 2020 [Epub ahead of print].

29. Guo W, Li M, Dong Y, Zhou H, Zhang Z, Tian C, et al. Diabetes is a risk factor for the progression and prognosis of COVID-19. Diabetes Metab Res Rev. 2020 [Epub ahead of print].

30. Han YN, Feng ZW, Sun LN, Ren XX, Wang H, Xue YM, et al. A comparative-descriptive analysis of clinical characteristics in 2019-coronavirusinfected children and adults. J Med Virol. 2020 [Epub ahead of print].

31. He Y, Li W, Wang Z, Chen H, Tian L, Liu D, et al. Nosocomial infection among patients with COVID-19: a retrospective data analysis of 918 cases from a single center in Wuhan, China. Infect Control Hosp Eepidemiol. 2020 [Epub ahead of print]

32. Jin X, Lian JS, Hu JH, Gao J, Zheng L, Zhang YM, et al. Epidemiological, clinical and virological characteristics of 74 cases of coronavirusinfected disease 2019 (COVID-19) with gastrointestinal symptoms. Gut. 2020;69:1002-9.

33. Li R, Tian J, Yang F, Lv L, Yu J, Sun G, et al. Clinical characteristics of 225 patients with COVID-19 in a tertiary Hospital near Wuhan, China. J Clin Virol. 2020;127:104363.

34. Li J, Wang X, Chen J, Zhang H, Deng A. Association of renin-angiotensin system inhibitors with severity or risk of death in patients with hypertension hospitalized for coronavirus disease 2019 (COVID-19) Infection in Wuhan, China. JAMA Cardiol. 2020 [Epub ahead of print].

35. Liu K, Chen Y, Lin R, Han K. Clinical features of COVID-19 in elderly patients: a comparison with young and middle-aged patients. J Infect. 2020 [Epub ahead of print]

36. Liu K, Fang YY, Deng Y, Liu W, Wang MF, Ma JP, et al. Clinical characteristics of novel coronavirus cases in tertiary hospitals in Hubei Province. Chin Med J. 2020 [Epub ahead of print].

37. Liu W, Tao ZW, Wang L, Yuan ML, Liu K, Zhou L, et al. Analysis of factors associated with disease outcomes in hospitalized patients with 2019 novel coronavirus disease. Chin Med J. 2020 [Epub ahead of print].

38. Liu Y, Du X, Chen J, Jin Y, Peng L, Wang HHX, et al. Neutrophil-to-lymphocyte ratio as an independent risk factor for mortality in hospitalized patients with COVID-19. J Infect. 2020 [Epub ahead of print].

39. McMichael TM, Currie DW, Clark S, Pogosjans S, Kay M, Schwartz NG, et al. Epidemiology of covid-19 in a long-term care facility in King County, Washington. N Engl J Med. 2020 [Epub ahead of print].

40. Myers LC, Parodi SM, Escobar GJ, Liu VX. Characteristics of hospitalized adults with COVID-19 in an integrated health care system in California. Jama. 2020 [Epub ahead of print].

41. Richardson S, Hirsch JS, Narasimhan M, Crawford JM, McGinn T, Davidson KW, et al. Presenting characteristics, comorbidities, and outcomes among 5700 patients hospitalized with COVID-19 in the New York City Area. Jama. 2020 [Epub ahead of print]

42. Shi H, Han X, Jiang N, Cao Y, Alwalid O, Gu J, et al. Radiological findings from 81 patients with COVID-19 pneumonia in Wuhan, China: a descriptive study. Lancet Infect Dis. 2020;20:425-34.

43. Simonnet A, Chetboun M, Poissy J, Raverdy V, Noulette J, Duhamel A, et al. High prevalence of obesity in severe acute respiratory syndrome coronavirus-2 (SARS-CoV-2) requiring invasive mechanical ventilation. Obesity (Silver Spring, Md). 2020 [Epub ahead of print].

44. Tan C, Huang Y, Shi F, Tan K, Ma Q, Chen Y, et al. C-reactive protein correlates with CT findings and predicts severe COVID-19 early. J Med Virol. 2020 [Epub ahead of print].

45. Tang N, Bai H, Chen X, Gong J, Li D, Sun Z. Anticoagulant treatment is associated with decreased mortality in severe coronavirus disease 2019 patients with coagulopathy. J Thromb Haemost. 2020;18:1094-9.

46. Wang L, He W, Yu X, Hu D, Bao M, Liu H, et al. Coronavirus Disease 2019 in elderly patients: characteristics and prognostic factors based on 4-week follow-up. J. Infect. 2020 [Epub ahead of print]. 
47. Wang Z, Yang B, Li Q, Wen L, Zhang R. Clinical features of 69 cases with coronavirus disease 2019 in Wuhan, China. Clin Infect Dis. 2020 [Epub ahead of print].

48. Xu B, Fan CY, Wang AL, Zou YL, Yu YH, He C, et al. Suppressed T cellmediated immunity in patients with COVID-19: a clinical retrospective study in Wuhan, China. J Infect. 2020 [Epub ahead of print].

49. Yuan M, Yin W, Tao Z, Tan W, Hu Y. Association of radiologic findings with mortality of patients infected with 2019 novel coronavirus in Wuhan, China. PLoS ONE. 2020;15:e0230548.

50. Zha L, Li S, Pan L, Tefsen B, Li Y, French N, et al. Corticosteroid treatment of patients with coronavirus disease 2019 (COVID-19). Med J. Aust. 2020 [Epub ahead of print].

51. Zhang JJ, Cao YY, Dong X, Wang BC, Liao MY, Lin J, et al. Distinct characteristics of COVID-19 patients with initial rRT-PCR-positive and rRT-PCRnegative results for SARS-CoV-2. Allergy. 2020 [Epub ahead of print].

52. Zhang P, Zhu L, Cai J, Lei F, Qin JJ, Xie J, et al. Association of inpatient use of angiotensin converting enzyme inhibitors and angiotensin II receptor blockers with mortality among patients with hypertension hospitalized with COVID-19. Circul Res. 2020. [Epub ahead of print].

53. Zhang L, Yan X, Fan Q, Liu H, Liu X, Liu Z, et al. D-dimer levels on admission to predict in-hospital mortality in patients with Covid-19. J Thromb Haemost. 2020 [Epub ahead of print].

54. Zhou Y, Han T, Chen J, Hou C, Hua L, He S, et al. Clinical and autoimmune characteristics of severe and critical cases of COVID-19. Clin TransI Sci. 2020 [Epub ahead of print].

55. Siontis GC, loannidis JP. Risk factors and interventions with statistically significant tiny effects. Int J Epidemiol. 2011:40:1292-307.

56. Mizumoto K and Chowell G. Estimating risk for death from 2019 novel coronavirus disease, China, January-February 2020. Emerg Infect Dis. 2020 [Epub ahead of print].

57. Preliminary estimates of the prevalence of selected underlying health conditions among patients with coronavirus disease 2019-United States, February 12-March 28, 2020. MMWR morbidity and mortality weekly report 2020; 69:382-386.

58. Sabatino J, De Rosa S, Di Salvo G, Indolfi C. Impact of cardiovascular risk profile on COVID-19 outcome. A meta-analysis. PLoS ONE. 2020;15:e0237131.
59. Dwyer T, Couper D, Walter SD. Sources of heterogeneity in the metaanalysis of observational studies: the example of SIDS and sleeping position. J Clin Epidemiol. 2001;54:440-7.

60. Chen T, Wu D, Chen H, Yan W, Yang D, Chen G, et al. Clinical characteristics of 113 deceased patients with coronavirus disease 2019: retrospective study. BMJ. 2020;368:m1091.

61. Giugliano D, Maiorino MI, Bellastella G, Chiodini P, Esposito K. Glycemic control, preexisting cardiovascular disease, and risk of major cardiovascular events in patients with type 2 diabetes mellitus: systematic review with meta-analysis of cardiovascular outcome trials and intensive glucose control trials. J Am Heart Assoc. 2019;8:e012356.

62. Imai Y, Kuba K, Rao S, Huan Y, Guo F, Guan B, et al. Angiotensinconverting enzyme 2 protects from severe acute lung failure. Nature. 2005;436:112-6.

63. Zheng YY, Ma YT, Zhang JY, Xie X. COVID-19 and the cardiovascular system. Nat Rev Cardiol. 2020[Epub ahead of print].

64. Mehra MR, Desai SS, Kuy S, Henry TD, Patel AN. Cardiovascular disease, drug therapy, and mortality in covid-19. N Engl J Med. 2020 [Epub ahead of print].

65. Farsalinos K, Barbouni A, Poulas K, Polosa R, Caponnetto P, Niaura R. Current smoking, former smoking, and adverse outcome among hospitalized COVID-19 patients: a systematic review and meta-analysis. Ther Adv Chronic Dis. 2020;11:2040622320935765.

66. Guan WJ, Liang WH, Zhao Y, Liang HR, Chen ZS, Li YM, et al. Comorbidity and its impact on 1590 patients with COVID-19 in China: a nationwide analysis. Eur Respir J. 2020b;55:2000547.

67. Williamson EJ, Walker AJ, Bhaskaran K, Bacon S, Bates C, Morton CE, et al. Factors associated with COVID-19-related death using OpenSAFELY. Nature. 2020;584(7821):430-6.

\section{Publisher's Note}

Springer Nature remains neutral with regard to jurisdictional claims in published maps and institutional affiliations.
Ready to submit your research? Choose BMC and benefit from:

- fast, convenient online submission

- thorough peer review by experienced researchers in your field

- rapid publication on acceptance

- support for research data, including large and complex data types

- gold Open Access which fosters wider collaboration and increased citations

- maximum visibility for your research: over $100 \mathrm{M}$ website views per year

At BMC, research is always in progress.

Learn more biomedcentral.com/submissions 